Cite: Mantsurov, I.G., Khrapunova, Ya.V., Makhonin, V.I. (2020). Ukrainian National Idea in the Context of the Democratic Solidarism Ideology. Demography and social economy, 2 (40), 35-49. https://doi.org/10.15407/dse2020.02.035

https://doi.org/10.15407/dse2020.02.035

UDC 342.571(477)

JEL Classification: O11, P16

I.G. MANTSUROV, Dr. Sc. (Economics), Prof., Corresponding Member

of the National Academy of Sciences of Ukraine

Director General of the Research Institute for System Statistical Studies

04053, Ukraine, Kyiv, Lvivska square, 14

E-mail: imantsurov@gmail.com

ORCID 0000-0003-1753-0422

Ya.V. KHRAPUNOVA, PhD (Economics), Docent of Statistical Department

SHEI "Kyiv National Economic University named after Vadym Hetman"

04053, Ukraine, Kyiv, Lvivska square, 14

E-mail: yakhrapunova@gmail.com

ORCID 0000-0002-6311-3235

V. I. MAKHONIN, PhD Student, Statistical Department

SHEI "Kyiv National Economic University named after Vadym Hetman"

04053, Ukraine, Kyiv, Lvivska square, 14

E-mail: vladyslavmakhonin@gmail.com

ORCID 0000-0001-8627-0754

\title{
UKRAINIAN NATIONAL IDEA \\ IN THE CONTEXT OF THE DEMOCRATIC SOLIDARISM IDEOLOGY
}

In the context of the crises aggravation Ukraine has been facing in recent months, we have to talk about an objective question regarding the need to formulate a new substance of the national idea, which would become the spiritual basis of state formation, as well as a factor of consolidation of Ukrainian society with the subsequent development of an appropriate level of national consciousness and the identity of the citizens of the country. However, the question of the basis on which the concept of the Ukrainian national idea should be formed is still controversial both in society and the expert community.

The purpose of the article is to form on the foundation of the democratic solidarism ideology such a concept that would include the determination of, in particular, basic national interests and public policy measures, the implementation of which, in turn, would contribute to the formation of the economic fundamentals of a new type of society, and namely - the state of solidary owners. 
It's proved that in terms of its substance, the national idea is a multidimensional and multilayer concept that forms a certain ideal as a guideline for the development of the nation and synthesizes fundamental values and interests which contribute to the harmonization of all social groups of the country's population.

It's emphasized that, being a spiritual category, the national idea includes, in particular, economic and political components, which should be reflected in program documents, state programs, strategies and practical activities of political parties, public organizations, etc.

It's shown, that that it is the state, which owns the fullness of national sovereignty and acts as the main mechanism for translation the national idea that should be first to formulate such an ideology of organizing the economic system that would be based on a fundamentally new, namely, solidary form of ownership. Developing this conceptual idea, the authors propose, firstly, to introduce into the scientific circulation the formulation of a number of fundamentally new economic categories, and, secondly, to improve those that are already used in the scientific literature.

It's determined on the basis of which particular sources the funds of universal basic income and lifetime prosperity can be formed. Formulating conclusions and recommendations, the authors prove that a vital level of the effectiveness of the functioning of the national economy can arise only under the system of its state regulation, which will be based on the above new and improved categories.

Keywords: Ukrainian national idea, the concept of democratic solidarism, economic categories, solidary ownership, universal basic income, lifetime prosperity, sources of social funds emergence, national economy regulation model, level and quality of life of the people.

A ghost is wandering around Ukraine, a ghost of SOLIDARISM

Introduction. In recent years - as, incidentally, always in the era of economic shocks and social turmoils - in Ukraine, the next stage of a broad political discussion about the Ukrainian national idea has been formed.

The authors consider the national idea as a complex, multidimensional and multilayer concept that synthesizes various fundamental values and interests, which, forming a certain ideal as a guideline for the development of the nation, contribute to the harmonization of all social groups of the country's population. Being a spiritual category, the national idea consists of economic and political elements, which, according to the authors, should be reflected in program documents and practical activities of political parties, public organizations, state programs, strategies, etc.

Given the critical importance and relevance of uniting the Ukrainian people on the platform of a national idea, the authors would like to emphasize: without a broad discussion of the concept of this idea, its deep understanding and consensual perception by all social groups and political forces, it's impossible not only to achieve unity in society, but also to begin coordinating the efforts of various social groups in this direction.

Following the authors' vision, the Ukrainian national idea should solve a twofold problem: firstly, to reflect the core national interests and, secondly, to set the optimal vector for the country's development. The above can be reali- 
zed by organically coordinating national interests in the political, economic, cultural and other fields, as well as by directing efforts to achieve ambitious goals related to the formation of a new, much more effective economic model, overcoming the crisis provoked, in particular, by the coronavirus COVID-19 pandemic, etc [16].

Moreover, interestingly enough, such a combination of national interests in different areas of public life is fully consistent with the important principles of inclusive development adopted in 2012 by the Council of the International Organization for Economic Cooperation and Development (OECD). These principles are a pan-European trend for further dynamic development.

Based on this understanding of the Ukrainian national idea as a starting point in achieving a dynamic and proportional inclusive development, the authors propose to consider the concept of a national idea both in its integral form, that is, in the form of a general national ideology, and in the form of its components - economic, foreign policy, cultural, military, etc.

It's rather obvious that the basis of the national idea of Ukraine should be an independent state. But it's doubtful that any of the readers would object to the fact that in the process of establishing the global world economic system, the main goal of the functioning of any state should be realization of the economic and social interests of its citizens.

Citizens with the opportunity to fulfil themselves and become wealthy and self-sufficient members of society will be interested in maintaining state independence and the security of such a state, which, pursuing a balanced economic and social policy, can ensure the implementation of high social standards.

Relevance of the paper. In this section, it should be noted: responding to the challenges of our time and formulating a vision of the Ukrainian national idea that absorbs the interests of all social groups of society in Ukraine, the authors substantiate the use for this purpose of the theoretical basis of the democratic solidarism ideology. At the same time, definitions of individual fundamentally new economic categories are introduced into the scientific circulation; moreover, the substantiation of proposals for deepening the categories that are already used in the scientific literature is carried out.

Literature overview. The space of the national idea in scientific research was firmly taken by the problem of ideology. The issues studied by scientists include the problem of the role of ideology in the modern state, the essential nature of any ideology, its principles, content and significance.

It's also important to note that various aspects of the formation of the Ukrainian national idea are studied in the works of famous Ukrainian scientists, namely: I. Bychko, V. Bebik [1], M. Golovaty, V. Rebkalo, S.Ya. Dashkevich [3], V. Zhmir, M. Zhulinsky, O. Zabuzhko [25], V. Ivanishin, F. Kanak, V. Kafarsky, F. Kirilyuk, V. Lisovy, V. Lizanchuk, S. Makarchuk, I. Makarovsky [15], Yu. Rimarenko, M. Rozumnyi [20], V. Sergiychuk, A. Fartushny [7]. 
Today, studies of modern ethnographers, which relate to the problems of national identity, can be considered especially important for understanding the phenomenon of "national idea."

Commending the theoretical and practical significance of the famous scientists' research, it should be noted that the identification of problems, prospects and the formation mechanism of the national idea of modern Ukraine - primarily in the context of its economic content - continues to be understudied aspect. Reflecting in this regard on the use of the solidarism ideology, it should be said that this aspect hasn't yet been covered in modern economic literature at all.

There were several stages in the development of solidarism, and at each of them it acted in a different capacity: in France, socio-economic aspects came to the forefront; in England — legal; in Italy and Germany — political; in Russia philosophical and metaphysical.

The process of understanding the conditions of social solidarity and attempts to conceptualize them in the format of political ideology date back to the philosophy of German romanticism - namely, to solidarism. Like many other philosophical and aesthetic phenomenon of "modernity", solidarism arose as a reaction to the disappointment in liberalism and the values of the Great French Revolution.

In the most holistic sound, the ideologists of solidarism, however, declared themselves in France, where at the beginning of the 20th century, solidarism had even been considered for some time as the official ideology of the Third Republic (1870-1940) and was intended to neutralize social antagonism and the growing class struggle that threatened the existence of the state. There, solidarism was considered primarily as a political or purely economic doctrine (Charles Gide, Célestin Charles Alfred Bouglé "Le solidarisme" [1907], Émile Durkheim "The Division of Labour in Society" [1893] [6], Léon Bourgeois "Solidarite" [1902], Eugène d' Eichthal "La Solidarité sociale" [1903], L. Fleurant "Sur la Solidarité" [1907]), and also as a specific legal theory of positivism (Léon Duguit, Maurice Hauriou).

It's noteworthy that the word "solidarism" was introduced into wide circulation in the 1840s by the French utopian philosopher, author of the doctrine of Christian Socialism and a disciple of Saint-Simon, Pierre Leroux (1797-1871) [22] (the term "socialism" also belongs to him) ${ }^{1}$.

After the end of World War I, solidarity ideas began to develop in Germany - among Catholics, in the context of the philosophy of neo-Thomism. The most eminent representatives of this trend were Heinrich Pesch and Gustav Gundlach, who called solidarism a social system [19], "which attaches real im-

\footnotetext{
${ }^{1}$ Tomism (the etymology linked with the name of Thomas Aquinas) is the official philosophy of Catholicism from 1879 to 1962, which is a Christian adaptation of Aristotle's philosophy. Neo-Thomism is a modern version of Thomism.
} 
portance to the solidarity of people, such as members of the natural community - starting with the family and ending with the state."

In secular social and political thought and philosophy, ideas about solidarity developed in two directions: 1) social and existential, according to which solidarism was perceived primarily as ontology and soteriology (the doctrine of salvation); 2) social and utilitarian, according to which it was perceived first of all, as a social technology. In other words, firstly, solidarity-as-collegiality and unity and, secondly, solidarity-as-mutual-assistance.

In fact, it should be especially noted that one of the first ideologists of solidarism, in whose work the theme of social solidarity became dominant, French sociologist Émile Durkheim distinguished mechanical and organic social solidarity - on the basis of the existence or absence of individualization of subjects [6].

The ideas of solidarism at the time were actively developed among the Ukrainian emigration (foreign political elite), too. So, solidarism had been the official ideology of the OUN (m) (the Melnikovsky arm of the Organization of Ukrainian Nationalists) for a quarter century - in 1947-1972. Among the notable ideologists of a solidarity or close conservative and solidarity commitment, it's necessary to distinguish V. Lipinsky [1], D. Dontsov [5], Yu. Lipa [23], O. Boduynik, V. Daniliv [2], as well as the "Soyuz getmanciv-derzhavnikiv" activists- associates of the hetman Pavlo Skoropadsky [15]. In that environment, there had been an opinion that solidarism was especially close to Ukrainian society due to the long statelessness of Ukraine and the lack of strong monocentric power. The foregoing had been manifested both in the long-standing experience of The Zaporozhian Cossacks, and in the more recent experience of the Makhnovist movement.

In recent years, the scientific bases of a number of countries were enriched with solid monographic publications on the problem of developing a democratic model of the modern economy. Among these publications, the most vivid and deep are the works of the founders of this problem - Russian scientists, economists, professors S.G. Belyaev and V.I. Koshkin [13].

Today, the terms "solidarity" and "solidarism" are used in the names and programs of some Ukrainian political parties, as well as in its slogans. At the same time, it's often difficult to understand from these slogans the essence of its solidary political and economic position, if it exists at all.

The purpose of the article. The purpose of the article is to develop the theoretical and methodological foundations of the democratic solidarism ideology and apply this concept in the process of forming a vision of the Ukrainian national idea, which would reflect a realistic perspective on the future and take into account the interests of all social groups of Ukrainian society. It should be noted that the analysis of the different social groups' interests is of undoubted theoretical and practical interest, but there is a subject of separate study.

According to the authors, such a vision should take into account, inter alia, basic national interests and, as a result, must lay the basis of public policy measu- 
res, the implementation of which will contribute to the formation of the economic foundations of a new type of society, namely - the state of solidary owners.

Formulation of the problem and the article's novelty. The novelty of the scientific research is attributable to the following: in the process of establishing their own vision of the Ukrainian national idea, the authors develop and deepen for this purpose the conceptual basis of a new direction of economic thought - the democratic solidarism ideology. This is realized, among other things, on the basis of streamlining the conceptual framework and the authors' vision of a number of fundamentally new economic categories.

It should be noted that attempts to deeply substantiate the ideology of democratic solidarism and harmoniously synthesize it with the concept of the Ukrainian national idea haven't yet been carried out in modern scientific economic literature.

Methods and data. The theoretical and methodological foundation for determining the Ukrainian national idea on the basis of the democratic solidarism ideology is determined by the specifics of a set of social and political principles that focus on the analysis of the national idea phenomenon [25] and its specific features in the conditions of the formation of independent Ukraine in the post-Soviet period.

In preparing the article, the author used historical, political and cultural approaches. It's impossible to develop the specifics of the phenomenon of the Ukrainian national idea and its interpretations in the context of the ideology of solidarism outside these approaches. In particular, general scientific methods of comparative analysis, systematization, and conceptual generalization were applied. The authors rely on the scientific works of foreign and domestic experts in this field.

Main results of the research. In the process of in-depth analysis and creative synthesis, the ideas expressed in modern economic literature allowed the authors to draw a conceptually important conclusion regarding the definition of a national idea. The authors have formed two meanings of the concept of "national idea." In a broad sense, it is a system of ideas and value principles that underlie the consolidation and development of Ukrainian society; in a narrow sense, this is a system of ideas related to value orientations in the area of ethnic identity of Ukrainians as a nation.

Recently, however, we can single out the tendency towards a different approach to prevail, according to which the national idea acts as an awareness of not only national, but also civilizational identity.

The authors argue that each formed state has a national idea. In other words, a nation is a people with a national idea. That is, it's similar in structure, function and purpose, and its specificity is associated with the identity of countries.

The national idea is inextricably linked with the process of state building and institutionalization of national relations. Sometimes it has a religious connotation. Although there are multiconfessional formed states [20]. 
The experience of post-Soviet independent Ukraine shows that it is impossible to realize a national idea without a strong economy. At the same time, nothing new and promising can be built on the rules of economic behavior existing in Ukraine today [3].

It's certainly true that the experience of transforming the administrative model of the Ukrainian economy into a market one cannot be considered successful. Which, in turn, means that there is no way to do it without a new public treaty, nor can it be done without fulfilling the obligations contained in this treaty.

It should also be emphasized that the authors note the lack of the desire of the majority of the modern Ukrainian political elite representatives to formulate and propose to society new rules for the economic establishment of society, which would be based on a fundamentally different methodological and ideological basis, and currently absent in Ukraine.

The reluctance (or inability) of the political elite representatives to demonstrate the will and desire to move away from stereotypes, dogmas and rudimentary norms in the formation of a social treaty is the reason that throughout the complex and sometimes tragic history of Ukraine, each of the ideologies of the past - nationalism, socialism, neoliberalism or communism - failed to correctly formulate the new rules, the implementation of which would contribute to the implementation of the Ukrainian national idea.

Researchers believe that today, Ukrainian parties basically adjust their position to the situation. With rare exceptions, they do not have systemic ideas and principles on which it's proposed to build a state and unite a nation. This trend indicates that Ukrainians are more inclined to unite around their leaders than around conceptual ideas.

At the same time, it should be remembered that in any society a national idea turns into a real power only when it takes possession of the masses. And for this, the idea must harmoniously transform into ideology. That is within the reach of a large political party, which has the necessary material, organizational and media resources, and is thus able to make the national idea a driving force for the revival of a nation and a state. That is, to build a formed state [8].

As it's known, the tasks of any party ideology include, firstly, the construction of meanings and motivations in order to characterize the present and modeling the future in accordance with party ideas of the values of this future and, secondly, the creation of an environment that would absorb the corresponding party ideas and implement them as a result of collective actions [2].

The authors believe that in relation to the concept of a national idea, such a political force, first of all, should have a clear understanding of the economic structure of society, which forms the basis, the framework of this concept. It's impossible to build a formed state without such an ideology.

As such an ideology, the authors propose to adopt the concept of solidarism based on economic democracy, justifying this by the fact that it's this approach 
that can unite society by combining different social groups and political forces with the idea of social solidarity. The latter, in turn, is considered to be the theoretical basis of the ideology and political philosophy of solidarism.

Solidarity usually - both in the past and today - is interpreted as a commonality of interests, single mind-set developing, unanimity, interdependence, interrelatedness, joint responsibility [18]. Solidarity can also be defined as the principle of social existence that involves the pooling of resources and capabilities of subjects of relations with a view to achieve common goals. Moreover, the interests of each of the subjects in this way are in balance with the interests of the community and aren't sacrificed to either abstract common interest or individual egoism. Thus, solidarity should be considered as a mechanism of social self-regulation, self-preservation and self-development of the collective organism (society), which allows you to maximize the opportunities of all members of society for an individual and common good [9].

Hence the organically derived definition of "solidarism" as the fundamental principle of building a social system based primarily on the harmonious combination of its various parts, and not on the struggle and fierce competition, which, unfortunately, is common to Ukrainian - and not only — society today.

In such a system, all members of society and social groups - families, ethnic groups, religious denominations, classes, political parties, business units, etc., have real legal and social and political subjectivity. Consequently, their rights, opportunities, interests and values can be consolidated and solidified in order to achieve consensus objectives (common good) within the social framework of various scales (local, national, global) [24].

At the same time, more importantly, taking into account Ukrainian realities, the elements between which solidarity relations arise retain their heterogeneity and diversity. Moreover, their uniqueness is precisely the basis for combining efforts and the emergence of a synergistic multiplying effect.

Thus, traditional solidarism is a theory of a kind of "good society" with developed mechanisms and institutions for reconciling the interests and values of all participants in social relations.

However, until recently, the theory of solidarism lacked an adequate political and economic platform [15]. This, in turn, blocked the conceptual development and practical implementation of a solidarity model of the economy.

In our opinion, this model is a social and economic system that combines the interests, goals and actions of the whole society - government, business, all social groups and citizens - in order to achieve the highest quality of life for all members of the society, regardless of gender, age, levels of education and welfare, belonging to a particular social group, region, etc., and based on dynamic and proportional inclusive development. The use of the main methodological provisions outlined in these publications makes it possible to lay the foundations of a solidary model of the economic component of the national idea concept of Ukraine [20]. 
At the same time, assessing the demand for an ideology that can unite different and conflicting political forces, as well as social groups, the authors believe that solidarism [2] in its updated and scientifically reflexed form has the potential to become relevance in the 21 st century, a system of values, ideas and models of social reality. Particularly because the new social dynamics requires a fundamental update of the analytical tools, as well as the reformulation of the values of various political parties, social groups, and, most importantly, entities engaged in the design and modeling of the future, and the implementation of programs to transform these models into real life [24].

Thus, it seems that the answers to many questions and challenges of the present, to which other modern scientific theories have no convincing, and, most importantly, effective and efficient answers, can be formulated only within the framework of ideology, political philosophy and the economic theory of solidarism.

It's especially important to note that the main goal of the solidary way of production is the dynamic and proportional inclusive development of society, which ensures unconditional and guaranteed satisfaction of the growing demand (both material and intellectual, and civilizational) of all social groups and individuals, regardless of their gender, age, ethnicity, level of education and profession.

Without overloading the reader with complex theoretical analysis, the authors would like to dwell briefly on the characteristics of key economic categories, focusing on those details that will help to understand the essence of the model of modern solidarism.

Solidary property. Classical political economy has always considered property as the core category that permeates the totality of production relations of any mode of production. To reveal the substance of property means to give comprehensive picture of the features of the formation and development of a certain system of economic relations [17].

Such a political and economic characteristic implies the study of property relations in the inextricable unity of its three fundamental parameters, namely: 1) property as a condition of the reproduction process; 2 ) property as a result of reproduction; 3 ) property as an element of the organization of reproduction, the characteristics of which distinguish it from previous or subsequent ones.

In the course of the historical development of a market economy - due to the simultaneous progress of the productive forces - the forms of private property objectively has been undergoing a transformation, too.

The following is a theoretical model, the materialization of which allows not only to understand the interpretation of the category "property" in the context of solidarism, but also, most importantly, to evaluate the benefits that a solidary transformation of private property provides to all members of society.

This theoretical model, developed about a decade ago by the previously mentioned Russian economists, professors S.G. Belyaev and V.I. Koshkin [12] 
introduces a new economic category into the scientific circulation - the associated private property of citizens (hereinafter referred to as APPC).

The authors emphasize that on the descent-based basis, the APPC is private property, since the citizen-owner to whom it brings income has a specific right assigned to it - the right of ownership. At the same time, the APPC is characterized by some significant differences from traditional forms of private capitalist ownership.

Solidifying of ownership, in turn, is fundamentally different from privatization under capitalism. If capitalist privatization, as shown by the experience of Ukraine and almost all countries in the post-Soviet space, was essentially a redistribution of property, primarily in the interests of large capital and government officials, then the point of solidifying property is to give private ownership to all citizens of the country.

It should also be borne in mind that the solidifying of property is fundamentally different from nationalization. This difference is that nationalization implies the transfer of private property into the hands of the bureaucracy (decision-makers in the state) with all the ensuing corruption consequences, while the solidifying of property consists in the personification of rights to own, dispose and use for each citizen.

Taking into account all of the above, the authors would like to recommend today, first conceptually, and subsequently, after a nationwide discussion, legislatively consolidate the institution of associated private property of citizens in the concept of the economic component of the national idea of Ukraine [20].

We believe that a new political force, which absorbs the ideology of democratic solidarism and pursues it in the form of the economic component of the national idea of Ukraine, could initiate appropriate constitutional changes, or, at the first stage, include the provision on the associated private property of citizens in its political program. This would create real prerequisites for the transformation of such categories of market economy as "minimum wage", "living wage", "pension" in the form of a national idea into conceptually new categories, namely, "universal basic income" and "lifetime prosperity" of citizens.

Universal basic income. Speaking about this category, professors S.G. Belyaev and V.I. Koshkin [12] rightly note that the institution of universal basic income (UBI) isn't their invention. So, from the mid-twentieth century to the present day, among the world scientific community, in political circles and several governments of European countries (Switzerland, for example), discussions have been arising regarding the feasibility of introducing the UBI for all categories of citizens.

The $U B I$ is a social concept that implies the regular payment of a certain amount of money to each member of the society by the state. Payments are made to all members of society, regardless of the income level and without the need to perform any kind of work. 
It should be noted that in January 2018, the issue of the UBI was discussed by the Parliamentary Assembly of the Council of Europe, and before that it had been tested in a number of European countries. Proponents of the implementation of the UBI compared the implementation of such a reform with the abolition of slavery or the realization of universal suffrage. A decision on its use, however, hasn't yet been made.

It appears that in the conditions of a constant government budget deficit in Ukraine, as well as in the presence of a huge outstanding public debt, the reality of administrating the UBI at the expense of the state budget is very doubtful. At the same time, trying to form a mechanism for the formation of the sources of the UBI fund and its fair distribution, the authors came to the conclusion that this can be achieved solely on the basis of democratic solidifying of the economy and the introduction of the APPC institution, which will create a solid economic base for the formation of the UBI.

Under these conditions, the major sources of the UBI could be:

- a legislatively determined share of rent payments for the use of natural resources;

- a share of income to the budget from socialized intellectual property created by citizens of Ukraine;

- a certain share of the enterprises income determined by the Budget Code of Ukraine.

Taking into account the poor financial state of Ukrainian social funds in particular, the Pension Fund the budget hole of which has already reached 170 billion hryvnas [26] — we believe that one of the main elements of the economic component of the national idea of Ukraine should be a methodology for determining lifetime prosperity of the citizens.

Lifetime prosperity. This is a new category that hasn't previously been used in countries with market economies. There are proposals, according to which, a system for ensuring a decent level of lifetime prosperity should include:

\section{The UBI + Remuneration + Dividends from ownership of the capital}

A fundamentally new system of administrating social benefits will function effectively throughout the life of every citizen of Ukraine. From birth and until reaching working age - at the expense of the UBI funds, to which, as a result of labor activity, payment for labor is added; and on reaching retirement age, the prosperity of citizens will be reliably guaranteed by the UBI funds and previously accumulated incomes.

In our opinion, the use of the institution of lifetime prosperity in the format of the concept of a national idea would meet two extremely important tasks making social funds solvent and, last but not least, starting to approach the standards of the inclusive development model recommended by influential interna- 
tional organizations through overcoming the enormous gap between income levels of different social groups.

In preparing this article, the authors aimed, firstly, to demonstrate how the use of a solidary approach could contribute to the formation, development and popularization of the Ukrainian national idea, and, secondly, to study the significance of the further movement towards a solidary planned market economy in the implementation of the national idea in life.

Conclusions. The article substantiates the innovative position of the authors regarding the development of conceptual foundations for determining the substance of the Ukrainian national idea based on the democratic solidarism ideology. At the same time, the authors consider the national idea as a complex, multidimensional and multilayer concept that synthesizes various fundamental values and interests, which, forming a certain ideal as a guideline for the development of the nation, contribute to the harmonization of all social groups of the country's population. This approach is explained by the fact that such a combination of national interests in different areas of public life is fully consistent with the important principles of inclusive development adopted in 2012 by the Council of the International Organization for Economic Cooperation and Development (OECD). These principles are a pan-European trend for further dynamic development.

Analyzing the trends of modern political life in Ukraine, the authors conclude regarding the lack of the desire of the majority of the modern Ukrainian political elite representatives to formulate and propose to society new rules for the economic establishment of society, which would be based on a fundamentally different methodological and ideological basis, and currently absent in Ukraine.

As such an ideology, the authors propose to adopt the concept of solidarism based on economic democracy, justifying this by the fact that it's this approach that can unite society by combining different social groups and political forces with the idea of social solidarity. The latter, in turn, is considered to be the theoretical basis of the ideology and political philosophy of solidarism.

Developing and deepening this ideology, the article offers authors' definitions of a number of fundamentally new economic categories, the wording of which is substantiated in the economic literature for the first time.

Justifying a fundamentally new system of administrating social benefits, the authors argue that in this format, social funds would become much more solvent, which, in turn, would allow them to start approaching the standards of the inclusive development model recommended by influential international organizations.

All of the above allows the authors to draw a generalized conclusion that the use of a solidary approach could contribute to the formation, development and popularization of the Ukrainian national idea, as well as laying the foundations of a new state regulation system of the solidary planned market economy of Ukraine. 


\section{REFERENCES}

1. Bebyk, V., Samoilenko, O. (2007). Terytorialnyi patriotyzm - peredumova derzhavotvorennia (zvertaiuchys do pohliadiv Viacheslava Lypynskoho). Viche. No. 4. S. 65.

2. Danyliv, V.Yu. (2000). Solidarnist i solidaryzm / per. z nim. I. Andrushchenka i D. Pavlyuk. Kyiv: Akademia. $152 \mathrm{s.}$

3. Dashkevych, Ya. (1993). Perehuk vikiv: try pohliady na mynule i suchasne Ukrainy. Ukraina: Nauka i kultura. Vyp. 26-27. S. 44-78.

4. Dontsov, D. (2011). Suchasne politychne polozhennia natsii i nashi zavdannia. Vybrani tvory: u 10 t. T. 1: Politychna analityka (1912-1918 rr.) / Uporyad., pislyam., koment. O. Bahan. Drohobych: Vidrodzhennya, S. 23-32.

5. Dontsov, D. (2012). Moderne moskvofilstvo. Vybrani tvory: u 10 t. T. 2: Kulturolohichna ta istoriosofska eseyistka (1911-1939) / Uporyad., pislyam., koment. O. Bahan. Drohobych: Vidrodzhennia, S. 18.

6. Dyurkheim, E. (1991). O razdeleniy obshchestvennoho truda. Moskow: Nauka, 575 s.

7. Fartushnyi, A.A. (2000). Ukrayinska natsionalna ideia yak pidstava derzhavotvorennia. Lviv, S. 288.

8. Fedotova, V.H. (2005). Khoroshee obshchestvo. Moscow.

9. Galbraith, J.K. (1996). The Good Sotsiety: The Humane Agenda. Boston - N.Y.

10. Helbreit, D. (2009). Ekonomika nevynnoho obmana: pravda nasheho vremeny: nauchno populyarnoe izdanie. Moskow: Evropa.

11. Khëffner, Y. (2001) Khrystyanskoe sotsyalnoe uchenie. Moscow. S. 431.

12. Koshkin, V.I. (2013). Rynochnaya ekonomika Rossii: put' k demokratiy. Politekonomicheskiye ocherki, Moscow: Ekonomika. S. 361.

13. Koshkin, V.I. (2015) Problemy formirovaniya solidarnoy ekonomiky. Ekonomika i upravleniye sobstvennost'yu, No. 4.

14. Kretov, S.I. (2015). Politicheskaya ekonomiya budushchego. Humanisticheskaya obshchestvenno-ekonomicheskaya formatsyia, t. 1.

15. Makarovskyi, I. (1996). Natsionalna ideia, politychna ideolohiya ta kultura. Ivano-Frankivsk, $47 \mathrm{~s}$.

16. Mantsurov, I., Khrapunova, Y. (2020). Sostoianie mirovoi finansovoi sistemy v usloviakh pandemyi koronavirusa covid-19. Vector News. Retrieved from http://vnews.agency/news/ business/259552-sostoyanie-mirovoy-finansovoy-sistemy-v-usloviyah-pandemiikoronavirusa-covid-19.html

17. Matts, U. (1992). Ydeologya kak determinanta politiki v epokhu moderna. Poilys. No. 1-2. S. 139-140.

18. Okara, A.N. (2013). Solidaryzm: Zabytaia ideologiya XXI v. Politicheskaya nauka. No. 4. S. 146-155.

19. Pesch, N. (1924). Lehrbuch der Nationalokonomie. Freiburg im Breisgau, S. 432.

20. Rozumnyi, M. (2001). Ukrayinska ideia na tli tsyvilizatsiyi. Kyiv, S. 401.

21. Vaytszekker, E.U. fon, Kharhrouz, K., Smit, M. (2013). Faktor 5. Formula ustoichyvoho rosta. S. 368.

22. Volhin, V. (1957). P'er Leru - odin iz epihonov sen-simonizma. Iz istoryi obshchestvennykh dvyzhenyi i mezhdunarodnykh otnosheniy. Sb. statei pamiaty akad. E.V. Tarle. Moscow: Izdatelstvo AN SSSR.

23. Vseukrayiinska trylohiia (2007): [u 2 t.] / Yuriy Lypa; [uporyad.: O. Myslyva, V. Yaremenko; peredm. M. Holovatyy]. Kyiv: MAUP. (Biblioteka ukrayinoznavstva; vyp.12)

24. Wallerstein, I., Kollynz, R., Mann, M., Derluh'yan, H., Kalkhun, K. (2017). Does Tsapitalism Have a Future? Moscow: Izd-vo Instytuta Haidara, S. 25. 
25. Zabuzhko, O. (2006). Filosofiia ukrayinskoyi idei ta yevropeyskyi kontekst: frankivskyi period. Kyiv: Fakt, $154 \mathrm{~s}$.

26. 170-miliardnyi defitsyt Pensiinoho fondu profinansuiut $\mathrm{z}$ derzhbiudzhetu. Ekonomichna pravda. Retrieved from https://www.epravda.com.ua/rus/news/2019/01/17/644362/ [in Ukraine].

Article submited on 10.04 .2020

Стаття надійшла до редакції 10.04.2020

I.Г. Манцуров, чл.-кор. НАН України, д-р екон. наук, проф.

директор Інституту системних статистичних досліджень

03150, Україна, Київ, Р.О. Вох 159

E-mail: imantsurov@gmail.com

ORCID 0000-0003-1753-0422

Я.В. Храпунова, канд. екон. наук, доц. каф. статистики

ДВНЗ «Київський національний економічний університет імені Вадима Гетьмана»

04053, Україна, Київ, Львівська площа, 14

E-mail: yakhrapunova@gmail.com

ORCID 0000-0002-6311-3235

B.I. Махонін, асп. каф. статистики

ДВНЗ «Київський національний економічний університет імені Вадима Гетьмана» 04053, Україна, Київ, Львівська площа, 14

E-mail: vladyslavmakhonin@gmail.com

ORCID 0000-0001-8627-0754

\section{УКРАЇНСЬКА НАЦІОНАЛЬНА ІДЕЯ У КОНТЕКСТІ ІДЕОЛОГІЇ ДЕМОКРАТИЧНОГО СОЛІДАРИЗМУ}

В умовах загострення викликів, з якими зіштовхнулась Україна протягом останніх декількох місяців, об'єктивно постало питання про необхідність формулювання нового змісту національної ідеї, яка 6 стала чинником консолідації українського суспільства, формування відповідного рівня національної самосвідомості й ідентичності громадян країни, духовною основою державотворення. Проте, до иьього часу в суспільстві та в експертному середовищі дискусійним є питання стосовно того, на якій основі має формуватися концепт української національної ідеї. Мета статті полягає у формулюванні такого кониепту на засадах ідеології демократичного солідаризму, що передбачає визначення, зокрема, базових начіональних інтересів і заходів державної політики, реалізація яких сприятиме формуванню економічних основ суспільства нового типу - держави солідарних власників. Доведено, щзо за змістом національна ідея - багатоаспектне, багатогранне поняття, яке синтезує фундаментальні изінності й ін-

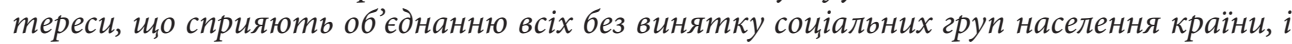
формує певний ідеал як мету розвитку нації. Наголошено, щз як духовна категорія вона умішує й економічну та політичну складові, які мають бути відображені у програмних документах і практичній діяльності політичних партій, громадських організацій, державних програмах, стратегіях тощо. Визначено, що саме держава, яка володіє усією повнотою національного суверенітету і $є$ головним механізмом втілення в життя національної ідеї, насамперед має сформувати таку ідеологію організації економічної системи, яку було б засновано на принципово новій, солідарній, формі власності. Розвиваючи июю концептуальну ідею, автори пропонують увести у науковий обіг 
формулювання ряду приниипово нових економічних категорій $і$ вдосконалити декілька таких, що вже використовуються в науковій тітературі. Визначено, на основі яких саме джерел можуть формуватися фонди безумовного базового доходу та пожиттєвого достатку. Формулюючи висновки та рекомендаціі, автори доводять, що життєво необхідний рівень ебективності функціонування національної економіки може забезпечити тільки така система ї державного регулювання, яка будуватиметься на ицх нових і удосконалених економічних категоріях.

Ключові слова: Українська національна ідея, концепція демократичного солідаризму, економічні категорії, солідарна власність, безумовний базовий дохід, пожиттєвий достаток, джерела формування соціальних фондів, модель регулювання національної економіки, рівень та якість життя народу. 